http:/www.journals.zu.edu.eg/journalDisplay.aspx?Journalld=1\&queryType=Master

\title{
MORPHOLOGICAL IDENTIFICATION AND EVALUATE THE COMBINING ABILITY AND HETEROSIS OF SOME INBRED LINES OF
} MAIZE AND ITS CROSSES

\author{
Eman A. Fayed ${ }^{1}$, A.A.A. Lelah ${ }^{2}$, El-Shimaa E.I. Mostafa ${ }^{1}$ and S.F. Morgan ${ }^{3}$ \\ 1. Seed Technol. Res. Dept., Agric. Res. Cent., Egypt \\ 2. Agron. Dept., Fac. Agric., Mansoura Univ., Egypt \\ 3. Maize Res. Dept., Agric. Res. Cent., Egypt
}

Received: 18/08/2019; Accepted: 27/10/2019

\begin{abstract}
In 2016 five maize inbred lines were crossed in all possible combinations without reciprocals by using a half diallel crosses mating design to obtain 10 single crosses. Parental inbred lines and their $F_{1}$ single crosses were evaluated through 2017 season to evaluate the role of general and specific combining ability, heterosis and the morphological characteristics. A randomized complete block design with three replicates was used. Results showed that mean squares of genotypes, general combining ability (GCA) and specific combining ability (SCA) were highly significant for all studied yield traits. The GCA/SCA ratio was less than unity for all studied traits, this means that these traits are predominantly controlled by non-additive gene action. Positive significant GCA effects were found for all studied traits. Based on GCA estimates, it could be concluded that the best combiners were Inb 209 and Inb 239 for most of studied traits. This result indicated that these inbred lines could be considered as good combiners for improving yield and its attributes. Positive significant SCA effects were found for all studied traits. Based on SCA effects, the best crosses for ear diameter, 100-kernel weigh and kernel number/row was $\mathrm{C}$; f for ear length was $\mathrm{C} 10$ and for ear weight/plant, grain weight/plant and shelling percentage was $\mathrm{C} 8$. Results showed positive significant heterosis values for all studied yield traits. The best crosses over both their mid-parents and betterparents for ear diameter and 100-kernel weigh was C2; for ear length and kernel number/row was C5; for ear weight/plant and grain weight/plant was C9 and for shelling percentage was C8.
\end{abstract}

Key words: Maize, morphology, heterosis, half diallel crosses, general combining ability, specific combining ability.

\section{INTRODUCTION}

Allard (1960) was the first research worker who found that hybrids were often possessed the most striking and unusual vigor. Since that time, many research workers started a new area of plant breeding to benefit from this phenomenon, which is now known as heterosis. Abd El-Aal (2002) evaluated a set of halfdiallel crosses among eight inbred lines and the six populations of each cross. He found that heterosis values relative to the better parent were negative and significant for ear length, ear diameter, number of kernel/row and grain weight/plant. El-Shouny et al. (2003) reported that the GCA and SCA mean squares were highly significant for ear diameter, number of kernel/row and grain weight/plant. Meanwhile, the GCA/SCA ratio was larger than unity for all the studied traits except grain weight/plant,

\footnotetext{
*Corresponding author: Tel. : +201023655608

E-mail address: emanfayed76@gmail.com
} 
indicating that the GCA were important than SCA in the inheritance of these traits. Shafey $\boldsymbol{e t}$ al. (2003) studied 28 F1 hybrids of corn and their eight parental inbred lines and they obtained quite large and medium values of heterosis formost. Abd El-Maksoud et al. (2004) Estimates of combining ability and heterosis in some maize inbred lines for the important traits. El-Gazzar (2004) evaluated 28 F1 hybrids of maize and observed that the calculated values of heterosis were positive and highly significant for all studied vegetative and yield component traits. Barakat and Osman (2008) indicated that the tested inbred lines and testers exhibited significant GCA effects vary greatly according to the studied traits. The variance magnitude due to GCA for tested and tester lines was higher than that due to SCA for all studied traits, this indicates that additive genetic variance was the major source of variation responsible for the inheritance of these traits. Smith and Smith (1989) in USA stated that morphological traits have long been used to estimate systematic relationship in corn. They added that although morphology has proved useful for classifying corn races and populations, it may not be appropriate for elite breeding germplagm while (Cooke, 1999) reported that many of the morphological descriptors used are based on quantitative characters, the expression of which is affected by environmental factors as well as the limited number of useful descriptors of some species. El-Hawary et al. (2003) reported that the morphological differences among the tested eleven inbred lines in thirtyfour characteristics were very clear. Very slight stem zig-zag was found for all studied genotypes, except Gm. 30, Sd. 7 while tassel lateral branches were strongly recurved and $\mathrm{Sd}$. 63 just recurved, Gm. 2 had conical ear shape. They added that all genotypes had white color of top of grain and dorsal side of grain and obtained results showed that all studied genotypes had no differences in anthocyanin coloration of glumes of cob which were absent. El-Abady (2005) identified the variability among three inbred lines, two Single Crosses and one Three-Ways cross using morphological characters according to UPOV (1994) and found that there were significant differences among the genotypes studied in most of the characters studied. Badu et al. (2017) studied the advances in genetic enhancement of early and extra-early maize for Sub-Saharan Africa. The aim of this study was to determine the role of general and specific combining ability and heterosis for some agronomic traits. Also the morphological characters were evaluated for identification among maize crosses.

\section{MATERIALS AND METHODS}

Two field experiments were carried out at the Farm of the Agronomy Department, Faculty of Agriculture, Mansoura University and laboratories of Seed Technology Department, Field Crops Research Institute A.R.C. Giza, Egypt during 2016 and 2017 summer seasons. In 2016 five maize inbred lines were crossed in all possible combinations without reciprocals by using a half diallel crosses mating design to obtain 10 single crosses. These inbred lines were: Inb 202, Inb 204, Inb 208, Inb 209 and Inb 239. The seeds of all inbred lines were obtained from Maize Research Department, Field Crop Research Institute, Agricultural Research Center (ARC), Ministry of Agriculture and Land Reclamation, Egypt. Name and sources of the studied genotypes are listed in Table 1. Diallel analysis for General and Specific Combining Ability was done. Ten single crosses comprise a half diallel between 5 inbred parents. Data of all 15 genotypes were analyzed as randomized complete blocks with three replicates. General combining ability effects for the inbred parents, specific combining ability effects for cross combinations and their respective standard errors were computed using formulae given in Griffing (1956) method 2 model 1 (fixed effects). Showed in Table 2.

The relative importance of GCA to SCA was expressed as follows:

$\mathrm{K}^{2} \mathrm{GCA} / \mathrm{k}^{2} \mathrm{SCA}=\left[\left(\mathrm{MS}_{\mathrm{GCA}}-\mathrm{Ms}_{\mathrm{e}}\right) /(\mathrm{P}+2)\right] /\left(\mathrm{MS}_{\mathrm{SCA}}-\mathrm{Ms}_{\mathrm{e}}\right)$ where:

$\mathrm{MS}=$ mean squares

$\mathrm{P}=$ No. of parents

$\mathrm{k}^{2}=$ The average squares of effects

The studied traits were recorded by visual assessment as follows in Table 3. 
Table 1. Names and sources of the genotypes

\begin{tabular}{lll}
\hline Code & Name & Source \\
\hline I1 & Inb 202 & H-[1] myorten \\
I2 & Inb 204 & CP X 888 \\
I3 & Inb 208 & SD7 X G2-614 \\
I4 & Inb 209 & SD7 X G2-614 \\
I5 & Inb 239 & Turk-24 \\
C1 & - & Inb 202X204 \\
C2 & - & Inb 202X208 \\
C3 & - & Inb 202X209 \\
C4 & - & Inb 202X239 \\
C5 & - & Inb 204X208 \\
C6 & - & Inb 204X209 \\
C7 & - & Inb 204X239 \\
C8 & - & Inb 208X209 \\
C9 & - & Inb 208X239 \\
C10 & - & Inb 209X239
\end{tabular}

Table 2. Analysis of variance and expected mean squares for combining ability analysis

\begin{tabular}{lccc}
\hline SV & df & MS & E.M.S \\
\hline GCA & $\mathrm{P}-1$ & $\mathrm{Mg}$ & $\sigma_{\mathrm{e}}{ }^{2}+(\mathrm{p}+2)(1 / \mathrm{p}-1) \sum \mathrm{g}^{2} \mathrm{i}$ \\
SCA & $\mathrm{P}(\mathrm{P}-1) / 2$ & $\mathrm{Ms}$ & $\sigma^{2}{ }_{\mathrm{e}}+2 / \mathrm{p}(\mathrm{p}-1) \sum \mathrm{i} \sum \mathrm{j} \mathrm{S}^{2}{ }_{\mathrm{ij}}$ \\
Error & $(\mathrm{r}-1)(\mathrm{c}-1)$ & $\mathrm{Me}$ & $\sigma_{\mathrm{e}}^{2}$ \\
\hline
\end{tabular}

Where, $\mathrm{Me}=$ the error mean squares of the main randomized complete block design divided by number of replications $(\mathrm{Me}=$ $\mathrm{Me} / \mathrm{r})$. , $\mathrm{P}=$ number of parents. 
Table 3. Qualitative characters and its degree

\begin{tabular}{ll}
\hline Code & Character \\
\hline A1 & Anthocyanin coloration of sheath of first leaf.
\end{tabular}

A2 Shape of tip of first leaf.

A3 Attitude of blade on leaf just above upper ear.

A4 Degree of zig-zag of stem.

A5 Anthocyanin coloration of brace roots.

A6 Attitude of lateral branches in lower third of tassel.

A7 Spikelets density in middle third of main axis.

A8 Anthocyanin coloration of anthers in middle third of main axis on fresh anthers

A9 Anthocyanin coloration of silks.

A10 Ear shape.

A11 Grain type in middle third of ear.

\begin{tabular}{|c|c|}
\hline \multicolumn{2}{|l|}{ Degree } \\
\hline Absent or very weak & 1 \\
\hline Weak & 3 \\
\hline Medium & 5 \\
\hline Strong & 7 \\
\hline Very strong & 9 \\
\hline Pointed & 1 \\
\hline Pointed to round & 2 \\
\hline Round & 3 \\
\hline Round to spatulate & 4 \\
\hline Spatulate & 5 \\
\hline Straight & 1 \\
\hline Slightly recurved & 3 \\
\hline Recurved & 5 \\
\hline Strongly recurved & 7 \\
\hline \multicolumn{2}{|c|}{ Very Strongly recurved 9} \\
\hline Absent or very slight & 1 \\
\hline Slight & 2 \\
\hline Strong & 3 \\
\hline Absent or very weak & 1 \\
\hline Weak & 3 \\
\hline Medium & 5 \\
\hline Strong & 7 \\
\hline Very strong & 9 \\
\hline Straight & 1 \\
\hline Slightly recurved & 3 \\
\hline Recurved & 5 \\
\hline Strongly recurved & 7 \\
\hline \multicolumn{2}{|c|}{ Very Strongly recurved 9} \\
\hline Lax & 3 \\
\hline Medium & 5 \\
\hline Dense & 7 \\
\hline Absent or very weak & 1 \\
\hline Weak & 3 \\
\hline Medium & 5 \\
\hline Strong & 7 \\
\hline Very strong & 9 \\
\hline Absent & 1 \\
\hline Present & 9 \\
\hline Conical & 1 \\
\hline Conico- Cylindrical & 2 \\
\hline Cylindrical & 3 \\
\hline Flint & 1 \\
\hline Flint-like & 2 \\
\hline Intermediate & 3 \\
\hline Dent-like & 4 \\
\hline Dent & 5 \\
\hline Sweet & 6 \\
\hline Pop & 7 \\
\hline
\end{tabular}


Table 4. Quantitative characters and its stage

\begin{tabular}{llc}
\hline Code & \multicolumn{1}{c}{ Character } & Stage \\
\hline $\mathbf{A 1 2}$ & Angle between blade and stem. & 61 \\
$\mathbf{A 1 3}$ & Angle between main axis and lateral branches in lower third of tassel. & 65 \\
$\mathbf{A 1 4}$ & Primary lateral branche number. & 65 \\
$\mathbf{A 1 5}$ & Time of tassel emergence (day). & 65 \\
$\mathbf{A 1 6}$ & Time of silk emergence (day). & 65 \\
$\mathbf{A 1 7}$ & Main axis above lowest side branch length $(\mathrm{cm})$. & 71 \\
$\mathbf{A 1 8}$ & Main axis above upper side branch length $(\mathrm{cm})$. & 71 \\
$\mathbf{A 1 9}$ & Tassel branches length (cm). & 71 \\
$\mathbf{A 2 0}$ & Blade width /cm (leaf of upper ear). & 75 \\
$\mathbf{A 2 1}$ & Blade length /cm (leaf of upper ear). & 75 \\
$\mathbf{A 2 2}$ & Ratio height of insertion of upper ear to plant height. & 75 \\
A23 & Peduncle length (cm). & 85 \\
A24 & Numbers of rows of grains /plant. & 92 \\
A25 & Ear diameter (cm). & 92 \\
A26 & Ear length without husk (cm). & 92 \\
\hline
\end{tabular}

\section{RESULTS AND DISCUSSION}

Results in Table 5 indicat that mean squares of genotypes, general combining ability mean squares (GCA) and specific combining ability mean squares (SCA) were highly significant for all studied traits. The GCA/SCA ratio was less than unity for all studied traits. This means that these traits are predominantly controlled by non-additive gene action. Similar results were previosly reported by Hassaballa et al. (2002) and El-Morshidy et al. (2003).

\section{General Combining Ability Effects $\left(g_{i}\right)$}

Results presented in Table 6 regarding estimates of general combining ability effects (gi) for inbred parents for studied traits showed that positive significant GCA effects were found for all studied traits. Based on GCA estimates, it indicated that the best combiners for ear diameter and ear length were inbred lines of Inb 209 and Inb 239; for kernel No./row were Inb 204; Inb 202 and Inb 209; for 100kernel weight were Inb 204 and Inb 209; for ear weight/plant and grain weight/plant was Inb 209 and for Shelling percentage was Inb 202. These results indicated that these inbred lines could be considered as good combiners for improving yield traits.

\section{Specific Combining Ability Effects $\left(\mathbf{S}_{\mathrm{ij}}\right)$}

Results given in Table 7 show $\left(\mathrm{s}_{\mathrm{ij}}\right)$ for all $\mathrm{F}_{1}$ crosses for all studied traits. Positive significant SCA effects were found in all studied traits for most crosses. Based on SCA effects, all crosses showed positive and significant SCA effects for ear diameter. It is interest to note that, maximum and desirable SCA effects were registered for ear height by C7 (Inb 204 X 239; for ear diameter and 100- kernel weight by C1 (Inb 202 X 204); for kernels/row by C2 (Inb 202 X 208) and as well as for ear yield/plant, grain yield/ plant and shelling (\%) by C8 (Inb 208 X 209). So $\mathrm{C} 1, \mathrm{C} 2, \mathrm{C} 7$ and $\mathrm{C} 8$ could be selected and used in breeding programs for improving these traits. This result is in contrast with previous findings by Hosana et al. (2015) who reported that additive variance effects were more important than non-additive genetic effects. The differences could be attributed to different sets of germplasm and different environments used in these studies. 
Table 5. Mean squares of five parental diallel crosses for all studied traits from analysis of variance, for (GCA) and (SCA) of all studied traits

\begin{tabular}{lcccccccc}
\hline SV & df & $\begin{array}{c}\text { Ear } \\
\text { length }\end{array}$ & $\begin{array}{c}\text { Ear } \\
\text { diameter }\end{array}$ & $\begin{array}{c}\text { Kernels/ } \\
\text { row }\end{array}$ & $\begin{array}{c}\text { 100-kernel } \\
\text { weight }\end{array}$ & $\begin{array}{c}\text { Ear yield/ } \\
\text { plant }\end{array}$ & $\begin{array}{c}\text { Grain yield/ } \\
\text { plant }\end{array}$ & $\begin{array}{c}\text { Shelling } \\
\text { (\%) }\end{array}$ \\
\hline Genotypes & 12 & $89.9^{* *}$ & $3.9^{* *}$ & $315.1^{* *}$ & $113.7^{* *}$ & $12210.1^{* *}$ & $9469.9^{* *}$ & $306.3^{* *}$ \\
GCA & 6 & $26.9^{* *}$ & $3.1^{* *}$ & $243.3^{* *}$ & $42.2^{* *}$ & $5750.2^{* *}$ & $3234.5^{* *}$ & $126.7^{* *}$ \\
SCA & 12 & $114.7^{* *}$ & $4.9^{* *}$ & $340.9^{* *}$ & $139.7^{* *}$ & $14789.9^{* *}$ & $11966.9^{* *}$ & $377.7^{* *}$ \\
Error & 40 & $1.3^{* *}$ & 0.1 & 5.1 & 0.6 & 29.7 & 46.3 & 21.6 \\
SCA/GCA & - & 0.03 & 0.08 & 0.10 & 0.04 & 0.07 & 0.04 & 0.05 \\
\hline
\end{tabular}

*** Significant at level probability 0.05 and 0.01 , respectively.

Table 6. Estimates of general combining ability effects (gi) for inbred parents for studied traits

\begin{tabular}{lccccccc}
\hline $\begin{array}{c}\text { Traits } \\
\text { Crosses }\end{array}$ & $\begin{array}{c}\text { Ear } \\
\text { length }\end{array}$ & $\begin{array}{c}\text { Ear } \\
\text { diameter }\end{array}$ & $\begin{array}{c}\text { Kernels } \\
\text { /row }\end{array}$ & $\begin{array}{c}\text { 100-kernel } \\
\text { weight }\end{array}$ & $\begin{array}{c}\text { Ear } \\
\text { yield/plant }\end{array}$ & $\begin{array}{c}\text { Grain } \\
\text { yield/plant }\end{array}$ & $\begin{array}{c}\text { Shelling } \\
(\%)\end{array}$ \\
\hline P1 (Inb202) & -0.391 & $-0.322^{* *}$ & $1.950^{* *}$ & $-1.245^{* *}$ & $-8.987^{* *}$ & $-7.100^{* *}$ & $2.320^{*}$ \\
P2 (Inb204) & 0.387 & $-0.412^{* *}$ & $2.100^{* *}$ & $0.671^{* *}$ & 0.411 & -0.233 & 0.214 \\
P3 (Inb208) & $-0.666^{*}$ & 0.08 & $-3.979^{* *}$ & 0.188 & $-9.100^{* *}$ & $-5.888^{* *}$ & $-3.217^{* *}$ \\
P4 (Inb209) & $1.716^{* *}$ & $0.397^{* *}$ & $1.656^{* *}$ & $1.685^{* *}$ & $24.546^{* *}$ & $19.100^{* *}$ & 0.911 \\
P5 (Inb239) & $0.912^{* *}$ & $0.092^{*}$ & $-1.822^{* *}$ & $-1.100^{* *}$ & $-6.580^{* *}$ & $-5.551^{* *}$ & -0.263 \\
SE $\left(\mathbf{g}_{\mathbf{j}}\right)^{\mathbf{1}}$ & 0.168 & 0.028 & 0.388 & 0.111 & 0.899 & 1.122 & 0.791 \\
SE $\left(\mathbf{g}_{\mathbf{i}}-\mathbf{g}_{\mathbf{j}}\right)^{\mathbf{2}}$ & 0.270 & 0.043 & 0.565 & 0.201 & 1.321 & 1.901 & 1.222 \\
\hline
\end{tabular}

*** significant at level probability 0.05 and 0.01 , respectively.

1 Standard error for an GCA effect.

2 Standard error for the difference between estimates of GCA effects.

Table 7. Estimates of (sij) for all F1 crosses for all studied traits

\begin{tabular}{|c|c|c|c|c|c|c|c|}
\hline Crosses & $\begin{array}{c}\text { Ear } \\
\text { length }\end{array}$ & $\begin{array}{c}\text { Ear } \\
\text { diameter }\end{array}$ & $\begin{array}{c}\text { Kernels / } \\
\text { row } \\
\end{array}$ & $\begin{array}{c}\text { 100- Kernel } \\
\text { weight }\end{array}$ & $\begin{array}{c}\text { Ear } \\
\text { yield/plant }\end{array}$ & $\begin{array}{c}\text { Grain } \\
\text { yield/plant }\end{array}$ & $\begin{array}{c}\begin{array}{c}\text { Shelling } \\
(\%)\end{array} \\
\end{array}$ \\
\hline C1 & $2.988 * *$ & $1.011 * *$ & $3.866^{* *}$ & $5.992^{* *}$ & $40.980 * *$ & $27.840 * *$ & -3.367 \\
\hline $\mathrm{C} 2$ & $4.887 * *$ & $0.924 * *$ & $9.667^{* *}$ & $0.257^{*}$ & $29.999 * *$ & $24.260 * *$ & $5.129 *$ \\
\hline C3 & 0.077 & $0.266^{* *}$ & $-3.106 * *$ & $1.370^{* *}$ & -2.100 & 3.397 & 1.748 \\
\hline C4 & -0.261 & $0.717 * *$ & $-0.430 \mathrm{~ns}$ & $4.817^{* *}$ & $42.955 * *$ & $37.719 * *$ & 2.674 \\
\hline C5 & $5.100 * *$ & $0.754 * *$ & $9.936^{* *}$ & $5.342^{* *}$ & $40.300 * *$ & $39.802 * *$ & $11.169 * *$ \\
\hline C6 & $1.850 * *$ & $0.221 * *$ & $6.988 * *$ & $2.516 * *$ & $25.620 * *$ & $20.492 * *$ & 0.597 \\
\hline C7 & $6.102 * *$ & $0.901 * *$ & $7.100^{* *}$ & $4.278^{* *}$ & $50.312 * *$ & $46.356 * *$ & $5.735^{*}$ \\
\hline C8 & $3.100 * *$ & $0.322 *$ & $3.010 * *$ & $2.120^{* *}$ & $55.100 * *$ & $57.869 * *$ & $12.402 * *$ \\
\hline C9 & $2.924 * *$ & $0.601 * *$ & $6.656^{* *}$ & $5.167^{* *}$ & $39.300 * *$ & $32.396 * *$ & $7.664 * *$ \\
\hline C10 & $-0.671 * *$ & $0.201 *$ & -2.010 & 0.241 & $8.998^{* *}$ & $7.763 *$ & 0.981 \\
\hline S.E sca (ij) ${ }^{1}$ & 0.47 & 0.070 & 0.96 & 0.34 & 2.32 & 2.96 & 2.03 \\
\hline S.E sca (ij-ik) ${ }^{2}$ & 0.72 & 0.1 & 1.52 & 0.5 & 3.83 & 4.44 & 3.04 \\
\hline S.E sca $(i j-k l)^{3}$ & 0.62 & 0.09 & 1.21 & 0.46 & 3.2 & 4.05 & 2.78 \\
\hline
\end{tabular}

*,** Significant at level probability 0.05 and 0.01 , respectively

1 Standard error for an SCA effect.

2 Standard error for the difference between two SCA effects for a common parent.

3 Standard error for the difference between two SCA effects for a non-common parent. 


\section{Heterosis Over Mid-Parents}

Results given in Table 8 show percentages of heterosis over mid-parents for all studied traits. Results showed positive significant heterosis values for all studied traits for all crosses except C3 (Inb 202 X 209) and C10 (Inb 209 X 239) for kernel No./row and C1 (Inb $202 \times$ 204) for shelling percentage. The maximum percentage of heterosis over their mid-parents for ear diameter and 100-kernel weight was C1 (Inb 202 X 204); for ear length, kernel No./row and for shelling percentage was C5 (Inb 204 X 208) and for ear weight/plant and grain weight/plant was C9 (Inb 208 X 239), similar results were reported by Mosa (2003) and Welcker et al. (2005).

\section{Heterosis Over Better-Parents}

Table 9 show percentages of heterosis over better-parents for all studied traits. Results showed positive significant heterosis values over better-parents in all studied traits for most crosses. The highest crosses over their betterparents for ear diameter and 100-kernel weight was C2(Inb 202 X 208); for ear length, kernel No./row and shelling percentage was C5 (Inb 204 X 208); for ear weight/plant and grain weight/plant was C9 (Inb 208 X 239) similar results were reported by Amiruzza man et al. (2010).

\section{Morphological Identification}

\section{Qualitative characters:}

As presented in Table 3 and the obtained results in Table 10, the morphological identification could be described as follows:

\section{Anthocyanin coloration of sheath of first leaf}

Inb 202, C1, C2, C3, C4, C5, C6, C8 and C10 were very strong, while Inb 204, Inb 208, Inb 239 and $\mathrm{C} 7$ were medium.

\section{Shape of tip of first leaf}

Was pointed for all genotypes.

Attitude of blade on leaf just above upper ear

Straight in (Inb 202, C2 and C8), slightly recurved in (Inb 204, Inb 208, Inb 209, C4, C6,
C7 and C9) and recurved in (Inb 239, C1, C3, $\mathrm{C} 5$ and $\mathrm{C} 10)$.

\section{Degree of zig-zag of stem}

Slight in (Inb 208 and C2) and C10, absent or very slight in (Inb 202, Inb 239, C1, C3, C4, C5, C6, C8, C9 and C10) and absent in (Inb 209 and $\mathrm{C} 7$ ).

\section{Anthocyanin coloration of brace roots}

Was strong in all genotypes.

Anthocyanin coloration at base of glume in middle third of main axis

Present only in Inb 209, C3, C8 and C10.

Anthocyanin coloration of glumes excluding the base

Present in all genotypes except Inb 209 was absent.

\section{Attitude of lateral branches in lower third of} tassel

Was slightly recurved in all genotypes.

Anthocyanin coloration of anthers in middle third of main axis, on fresh anthers

Very strong in C6 only but Inb 204, Inb 208, Inb 209 and C5 were just strong while Inb 202, Inb239, C1, C4, C7, C8, C9 and C10 were medium but $\mathrm{C} 2$ and $\mathrm{C} 3$ were weak.

\section{Anthocyanin coloration of cob glumes}

Was absent for all studied crosses.

\section{Ear shape}

Conical in $\mathrm{C} 1, \mathrm{C} 5$ and $\mathrm{C} 6$, while $\mathrm{C} 2, \mathrm{C} 7$ and $\mathrm{C} 8$ were conico-cylindrical, whereas $\mathrm{C} 3, \mathrm{C} 4, \mathrm{C} 9$ and $\mathrm{C} 10$ were cylindrical.

\section{Grain type}

All studied crosses were dent in middle third of ear.

\section{Anthocyanin coloration of silks}

Present only in Inb 239, C4, C7, C9 and C10.

Similar results were reported by El-Hawary et al. (2003) and El-Abady (2005). 
Table 8. Percentages of heterosis over mid-parents for all studied traits.

\begin{tabular}{rccccccc}
\hline $\begin{array}{r}\text { Traits } \\
\text { Crosses }\end{array}$ & $\begin{array}{c}\text { Ear } \\
\text { length }\end{array}$ & $\begin{array}{c}\text { Ear } \\
\text { diameter }\end{array}$ & $\begin{array}{c}\text { Kernel } \\
\text { No./row }\end{array}$ & $\begin{array}{c}\text { 100-Kernel } \\
\text { weight }\end{array}$ & $\begin{array}{c}\text { Ear } \\
\text { yield/plant }\end{array}$ & $\begin{array}{c}\text { Grain } \\
\text { yield/plant }\end{array}$ & $\begin{array}{c}\text { Shelling } \\
\text { (\%) }\end{array}$ \\
\hline C1 & $100.85^{* *}$ & $153.96^{* *}$ & $51.69^{* *}$ & $102.73^{* *}$ & $215.52^{* *}$ & $222.16^{* *}$ & 2.26 \\
C2 & $132.37^{* *}$ & $105.38^{* *}$ & $103.97^{* *}$ & $47.27^{* *}$ & $255.43^{* *}$ & $311.42^{* *}$ & $23.66^{* *}$ \\
C3 & $23.51^{* *}$ & $43.1^{* *}$ & 2.01 & $34.9^{* *}$ & $53.48^{* *}$ & $71.86^{* *}$ & $9.5^{* *}$ \\
C4 & $37.66^{* *}$ & $90.06^{* *}$ & $18.27^{* *}$ & $93.9^{* *}$ & $226.06^{* *}$ & $260.48^{* *}$ & $11.39^{* *}$ \\
C5 & $182.66^{* *}$ & $103.33^{* *}$ & $172.42^{* *}$ & $36.14^{* *}$ & $327.29^{* *}$ & $464.85^{* *}$ & $38.1^{* *}$ \\
C6 & $55.05^{* *}$ & $43.41^{* *}$ & $57.01^{* *}$ & $50.09^{* *}$ & $96.91^{* *}$ & $118.17^{* *}$ & $11.22^{* *}$ \\
C7 & $132.3^{* *}$ & $104.57^{* *}$ & $75.72^{* *}$ & $37.43^{* *}$ & $277.711^{* *}$ & $349.36^{* *}$ & $19.24^{* *}$ \\
C8 & $72.64^{* *}$ & $36.49^{* *}$ & $59.49^{* *}$ & $29.07^{* *}$ & $150.14^{* *}$ & $219.07^{* *}$ & $40.5^{* *}$ \\
C9 & $117.8^{* *}$ & $69.43^{* *}$ & $113.68^{* *}$ & $87.35^{* *}$ & $344.29^{* *}$ & $479.29 * *$ & $34.33^{* *}$ \\
C10 & $18.1 * *$ & $31.11^{* *}$ & 6.97 & $31.56^{* *}$ & $77.44^{* *}$ & $98.82^{* *}$ & $12.99^{* *}$ \\
LSD 5\% & 1.06 & 0.16 & 2.24 & 0.78 & 5.58 & 6.83 & 4.68 \\
LSD 1\% & 1.5 & 0.23 & 3.17 & 1.1 & 7.89 & 9.65 & 6.62 \\
\hline
\end{tabular}

*,** Significant at level probability 0.05 and 0.01 , respectively.

Table 9. Percentages of heterosis over better-parents for all studied traits

\begin{tabular}{|c|c|c|c|c|c|c|c|}
\hline $\begin{array}{ll} & \text { Traits } \\
\text { Crosses } & \\
\end{array}$ & $\begin{array}{c}\text { Ear } \\
\text { length }\end{array}$ & $\begin{array}{c}\text { Ear } \\
\text { diameter }\end{array}$ & $\begin{array}{c}\text { Kernel } \\
\text { No./row } \\
\end{array}$ & $\begin{array}{c}\text { 100- Kernel } \\
\text { weight }\end{array}$ & $\begin{array}{c}\text { Ear } \\
\text { yield/plant }\end{array}$ & $\begin{array}{c}\text { Grain } \\
\text { yield/plant }\end{array}$ & $\begin{array}{c}\begin{array}{c}\text { Shelling } \\
(\%)\end{array} \\
\end{array}$ \\
\hline $\mathrm{C1}$ & $83.0 * *$ & $74.1 * *$ & $27.3 * *$ & $32.9 * *$ & $164.8 * *$ & $58.8^{* *}$ & 3.11 \\
\hline $\mathrm{C} 2$ & $79.4 * *$ & $136.6 * *$ & $29.8 * *$ & $91.9 * *$ & $204.1 * *$ & $194.9 * *$ & -3.3 \\
\hline $\mathrm{C3}$ & 1.4 & 3.4 & -0.8 & $6.4^{* *}$ & $7.2 * *$ & $23.7 * *$ & 4.18 \\
\hline C4 & $32.2 * *$ & $57.1 * *$ & 1.8 & $90.9 * *$ & $194.2^{* *}$ & $205.4 * *$ & 3.83 \\
\hline C5 & $144.7 * *$ & $62.7 * *$ & $83.7 * *$ & $79.6 * *$ & $226.5^{* *}$ & $292.9 * *$ & $20.49 * *$ \\
\hline C6 & $16.7 * *$ & $-0.7 * *$ & $31.3 * *$ & $18.9 * *$ & $34.7 * *$ & $48.9 * *$ & $10.75^{* *}$ \\
\hline C7 & $115.3 * *$ & $60 * *$ & $74.7 * *$ & $82.5 * *$ & $252.7^{* *}$ & $313.2 * *$ & $17.18 * *$ \\
\hline C8 & $18.1 * *$ & $11.9 * *$ & -1.6 & $17.2 * *$ & $49.4 * *$ & $82.4 * *$ & $22.14 * *$ \\
\hline C9 & $76.9 * *$ & $64.3 * *$ & $43.7 * *$ & $67.4 * *$ & $257.4^{* *}$ & $325.6^{* *}$ & $18.99 * *$ \\
\hline C10 & -6.1 & 10.2 & -10.1 & 2.7 & $17.01^{* *}$ & $29 . \wedge * *$ & $10.58 * *$ \\
\hline LSD 5\% & 1.3 & 0.2 & 2.6 & 1.0 & 6.4 & 7.9 & 5.4 \\
\hline LSD 1\% & 1.7 & 0.3 & 3.7 & 1.3 & 8.9 & 11.2 & 7.6 \\
\hline
\end{tabular}


Table 10. Differences in qualitative characters for identified genotypes

\begin{tabular}{|c|c|c|c|c|c|c|c|c|c|c|c|}
\hline $\begin{array}{ll}\text { Characters } \\
\text { Genotype }\end{array}$ & $\mathbf{A 1}$ & $\mathbf{A 2}$ & $\mathbf{A 3}$ & A4 & A5 & A6 & $\mathbf{A} 7$ & $\mathbf{A 8}$ & A9 & $\mathbf{A 1 0}$ & A11 \\
\hline I1 & 9 & 1 & 1 & 1 & 7 & 3 & 5 & 5 & 1 & 1 & 5 \\
\hline I2 & 5 & 1 & 3 & 1 & 7 & 3 & 5 & 7 & 1 & 1 & 5 \\
\hline I3 & 5 & 1 & 3 & 2 & 7 & 3 & 5 & 7 & 1 & 1 & 5 \\
\hline I4 & 9 & 1 & 3 & 1 & 7 & 3 & 5 & 7 & 1 & 1 & 5 \\
\hline I5 & 5 & 1 & 5 & 1 & 7 & 3 & 5 & 5 & 9 & 1 & 5 \\
\hline $\mathrm{C} 1$ & 9 & 1 & 5 & 1 & 7 & 3 & 5 & 5 & 1 & 1 & 5 \\
\hline $\mathrm{C2}$ & 9 & 1 & 1 & 2 & 7 & 3 & 5 & 3 & 1 & 2 & 5 \\
\hline $\mathbf{C 3}$ & 9 & 1 & 5 & 1 & 7 & 3 & 5 & 3 & 1 & 3 & 5 \\
\hline C4 & 9 & 1 & 3 & 1 & 7 & 3 & 5 & 5 & 9 & 3 & 5 \\
\hline C5 & 9 & 1 & 5 & 1 & 7 & 3 & 5 & 7 & 1 & 1 & 5 \\
\hline C6 & 9 & 1 & 3 & 1 & 7 & 3 & 5 & 9 & 1 & 1 & 5 \\
\hline C7 & 5 & 1 & 3 & 1 & 7 & 3 & 5 & 5 & 9 & 2 & 5 \\
\hline C8 & 9 & 1 & 1 & 1 & 7 & 3 & 5 & 5 & 1 & 2 & 5 \\
\hline C9 & 9 & 1 & 3 & 1 & 7 & 3 & 5 & 5 & 9 & 3 & 5 \\
\hline C10 & 9 & 1 & 5 & 1 & 7 & 3 & 5 & 5 & 9 & 3 & 5 \\
\hline
\end{tabular}

For genotypes name see Table (1), for characters name and its degree see Table (2).

\section{Quantitative Characters}

The results in Table 11 indicate that the crosses $\mathrm{C} 5, \mathrm{C} 6, \mathrm{C} 7, \mathrm{C} 8$ and $\mathrm{C} 10$ has a greatest angle between blade and stem $\left(30^{\circ}\right)$. Otherwise the lowest angle was obtained from $\mathrm{C} 2$ and $\mathrm{C} 3$ $\left(20^{\circ}\right)$. The cross $\mathrm{C} 5$ had a greatest angle between main axis and lateral branches in lower third of tassel which was $50^{\circ}$. The lowest angle between main axis and lateral branches in lower third of tassel $\left(15^{\circ}\right)$ was found in C6. C9 gave the highest number (28) of primary lateral branches, while the lowest number (14) was produced from $\mathrm{C} 4 . \mathrm{C} 1$ gave the highest number of days of tassel emergence (70 days). The lowest number of days to tassel emergence (59 days) was reported for C9 or C10. Fayed (2009) C1 gave the highest number of days to silk emergence (71 days). Meanwhile, the lowest number of days (62) was produced from C9 or C10. Soliman et al. (1995) and El-Batal et al. (1996). C8 gave the highest length $(55 \mathrm{~cm})$ of main axis above lowest side branch length $(\mathrm{cm})$. Meanwhile, the lowest length $(32 \mathrm{~cm})$ was produced from C4. Katta and Abd El-Aty (2002) and El-Abady (2005). C10 gave the highest length $(29 \mathrm{~cm})$ of main axis above upper side branch. Meanwhile, the lowest length (13 $\mathrm{cm})$ was produced from $\mathrm{C} 3$. Galarreta and
Alvarez (2001). The tallest ear length without husk $(22 \mathrm{~cm})$ was given by $\mathrm{C} 6$. On the other hand, the shortest ear $(16 \mathrm{~cm})$ was produced from $\mathrm{C} 4$.

The results in Table 12 indicate that the greatest length of tassel branches was produced from $\mathrm{C} 6$ which recorded $26 \mathrm{~cm}$. On the contrary, the lowest length $(15 \mathrm{~cm})$ was obtained from $\mathrm{C} 2$ and $\mathrm{C} 4$. The cross $\mathrm{C} 6$ had the longest blade length of leaf upper ear which recorded (108 $\mathrm{cm})$. On the other hand, the shortest blade leaf upper ear was resulted from $\mathrm{C} 4(83 \mathrm{~cm})$. The highest value of blade width of leaf of upper ear was produced from $\mathrm{C} 6$, which were $(10 \mathrm{~cm})$, and the lowest value was obtained from $\mathrm{C} 4$ (6 $\mathrm{cm})$. Mowafy (2003). The highest ratio height of insertion of upper ear to plant height 0.50 was produced from C9. On the contrary, the lowest ratio (0.41) was obtained from $\mathrm{C} 10$. The tallest peduncle was produced from $\mathrm{C} 4$, which was $18 \mathrm{~cm}$. The shortest peduncle was produced from $\mathrm{C} 5(6 \mathrm{~cm}) . \mathrm{C} 10$ gave the highest number of rows of grains/plant (17 rows), Meanwhile, the lowest number was (11 rows) produced from $\mathrm{C} 2$. $\mathrm{C} 10$ cross produced the maximum ear diameter in middle $(4.96 \mathrm{~cm})$. C5 was found to have the minimum ear diameter $(3.49 \mathrm{~cm})$ Banchero et al. (2000). 
Table 11. Angle between blade and stem $\left({ }^{\circ}\right)$, angle between main axis and lateral branches, primary lateral branches number, time of tassel emergence (day), time of silk emergence (day), main axis above lowest side branch length of tassels $(\mathrm{cm})$ and main axis above upper side branch length of tassels $(\mathrm{cm})$ for identified crosses

\begin{tabular}{ccccccccc}
\hline Crosses & Character & A12 & A13 & A14 & A15 & A16 & A17 & A18 \\
\hline C1 & 25 & 30 & 22 & 70 & 71 & 49 & 26 \\
C2 & 20 & 35 & 25 & 67 & 68 & 33 & 16 \\
C3 & 20 & 30 & 16 & 67 & 69 & 40 & 13 \\
C4 & 25 & 20 & 14 & 65 & 67 & 32 & 23 \\
C5 & 30 & 50 & 19 & 67 & 69 & 49 & 16 \\
C6 & 30 & 15 & 17 & 67 & 69 & 42 & 26 \\
C7 & 30 & 18 & 17 & 65 & 67 & 46 & 27 \\
C8 & 30 & 30 & 24 & 62 & 65 & 55 & 16 \\
C9 & 25 & 25 & 28 & 59 & 62 & 41 & 21 \\
C10 & 30 & 17 & 20 & 59 & 62 & 45 & 29 \\
LSD at 0.05 & 3.21 & 4.55 & 3.33 & 6.81 & 7.1 & 5.23 & 3.55 \\
\hline
\end{tabular}

Table 12. Tassel branches length $(\mathrm{cm})$, blade length $\mathrm{cm}$, blade width/cm, ratio height of upper ear insertion to plant height, peduncle length $(\mathrm{cm})$, numbers of rows of grains/plant, ear diameter in middle $(\mathrm{cm})$ and ear length without husk $(\mathrm{cm})$ for identified crosses

\begin{tabular}{|c|c|c|c|c|c|c|c|c|}
\hline Characters & A19 & $\mathbf{A 2 0}$ & $\mathbf{A 2 1}$ & $\mathbf{A 2 2}$ & $\mathbf{A 2 3}$ & A24 & A25 & A26 \\
\hline $\mathrm{C1}$ & 21 & 98 & 8 & 0.44 & 8 & 15 & 4.25 & 18 \\
\hline $\mathrm{C} 2$ & 15 & 99 & 9 & 0.42 & 12 & 11 & 4.76 & 19 \\
\hline C3 & 19 & 90 & 8 & 0.47 & 9 & 13 & 4.63 & 20 \\
\hline $\mathrm{C} 4$ & 15 & 83 & 6 & 0.44 & 18 & 13 & 4.59 & 16 \\
\hline $\mathrm{C5}$ & 19 & 93 & 9 & 0.49 & 6 & 14 & 3.94 & 17 \\
\hline C6 & 26 & 108 & 10 & 0.45 & 8 & 15 & 4.24 & 22 \\
\hline C7 & 20 & 84 & 8 & 0.49 & 8 & 13 & 4.64 & 19 \\
\hline C8 & 20 & 95 & 9 & 0.43 & 8 & 15 & 4.64 & 20 \\
\hline C9 & 18 & 90 & 9 & 0.50 & 12 & 15 & 4.78 & 18 \\
\hline $\mathrm{C10}$ & 17 & 87 & 7 & 0.41 & 16 & 17 & 4.96 & 18 \\
\hline LSD at 0.05 & 2.70 & 6.10 & 0.47 & 0.12 & 1.34 & 2.03 & 0.21 & 2.21 \\
\hline
\end{tabular}




\section{REFERENCES}

Abd El-Aal, A.M.A. (2002). Studies on mode of downy mildew disease resistance of some maize inbred lines and their hybrid combinations. Ph.D. Thesis, Fac. Agric., Cairo Univ., Egypt.

Abd El-Maksoud, M.M., A.M. El-Adl, Z.M. ElDiasty, A.A. Galal and R.S. Hassanin (2004). Estimates of combining ability and heterosis in some maize inbred lines for the important traits. J. Agric. Sci. Mansoura Univ., 29 (1): 133-143.

Allard, R.W. (1960). Principles of Plant Breeding. John Wiley and Sons, Inc. New York, London. Sydney.

Amiruzza man, M., M.A. Islam, L. Hassan and M.M. Rohman (2010). Combining ability and heterosis for yield and component characters in maize. Academic J. Plant Sci., 3 (2): 79-84.

Badu-Apraku B., M.A.B. Fakorede (2017). Advances in Genetic Enhancement of Early and Extra-Early Maize for Sub-Saharan Africa, Springer international Publishing AG, Morphology and physiology of maize. Chapter 3, pages 33-35.

Banchero, C.B., N. Bartoloni, M.A. Rapela, G. Marrassini and S. Renteria (2000). Determination of discriminatory traits in maize hybrids. Agron., 20 (8): 875-884.

Barakat, A.A. and M.M.A. Osman (2008). Gene action and combining ability estimates for some white promising maize inbred lines by top cross system. J. Agric. Sci., Mansoura Univ., 33 (10): 6995-7009.

Cooke, R.J. (1999). Modern methods for cultivar verification and transgenic plant challenge. Seed Sci. and Technol., 27: 669-680.

El-Abady, M.I. (2005). Morphological and biochemical identification of some maize genotypes. Ph.D. Thesis, Agron. Dept., Fac. Agric., Mansoura Univ., Egypt.

El-Batal, M.A., B.N. Ayad and M.H. AbdelGawad (1996). Flowering of diverse recent maize hybrids in relation to heat units and grain yield. Zagazig J. Agric. Res., 23 (4): 447-461.

El-Gazzar, A.I. (2004). Genetic variability in some maize inbred lines. M.Sc. Thesis, Fac. Agric., Mansoura Univ., Egypt.

El-Hawary, M.I., A.H. Selim and A.M. El-Galfy (2003). Variability assessment of some maize elite inbred lines using morphological and molecular methods. Egypt. J. Plant Breed., 7 (1): 109-125.

El-Morshidy, M.A., E.A. Hassaballa; Sh.F. Aboul-Saad and M.A. Ahmed (2003). Selection for drought tolerance in maize (Zea mays L.). The $3^{\text {rd }}$ Sci. Conf. Agric. Sci., Assiut, Oct., 1: 173-191.

El-Shouny, K.A., Olfat, H. EL-Bagoury; H.Y. El-Sherbieny and S.A. Al Ahmcd (2003). Combining ability estimates for yield and its components in yellow maize (Zea mays, L.) under two plant densities. Egypt. J. Plant Breed. 7(1): 399 - 417.

Fayed Eman, A. (2009). Morphological and physiological identification of some inbred lines and its crosses of maize. M. Sc. Thesis, Fac. Agric., Mansoura Univ., Egypt.

Galarreta, J.I. and A. Alvarez (2001). Morphological classification of maize landraces from Northern Spain. Genet. Res. and Crop Evolution, 48 (4): 391-400.

Griffing, B. (1956). Concept of general and specific combining ability in relation to diallel crossing systems. Aust. J. Biol. Sci., 9: 463-493.

Hassaballa, E.A., M.A. El-Morshidy, Sh.F. Aboul-Saad and M.A. Ahmed (2002). Combining ability and type of gene action in maize under favourable and water stress environments. $3^{\text {rd }}$ Sci. Conf. Agric. Sci., Assiut, Oct., 151-171.

Hosana, G.C., S. Alamerew, B. Tadesse and T. Menamo (2015). Test cross performance and combining ability of maize (Zea mays L.) inbred lines at Bako, Western Ethiopia. Global J. INC. (USA), 15 : 4.

Katta, Y.S. and M.S. Abd El-Aty (2002). Performance and phenotypic-genetic stability estimates of grain yield and its attributes in different environmental 
conditions for some maize hybrids. J. Agric. Sci. Mansoura Univ., 27 (6): 3647-3661.

Mosa, H.E. (2003). Heterosis and combining ability in maize (Zea mays L.). Minufiya J. Agric. Res., 28 (5): 1375 - 1386.

Mowafy, S.A.E. (2003). Response of some maize hybrids to nitrogen fertilizer splitting under drip irrigation system in sandy soils. Zagazig J. Agric. Res., 30 (1): 17-34.

Shafey, S.A., H.E. Yassien, I.E.M.A. El-Beially and O.A.M. GadOAlla (2003). Estimates of combining ability and heterosis effects for growth, earliness and yield in maize (Zea mays L.). Egypt. J. Agric. Sci., Mansoura Univ., 28 (1): 55 - 67.

Smith, J.S.C. and O.S. Smith (1989). The description and assessment of distance between inbred lines of maize: I- The use of morphological traits as descriptors. Maydica, 34: 141-150.

Soliman, P.M., A.S. Gouda, M.M. Ragheb and S.M. Amer (1995). Response of maize (Zea mays L.) hybrids to plant population density under different environmental conditions. Zagazig J. Agric. Res., 22 (3): 663-676.

UPOV (1994). The International Union for the Protection of New Varieties of Plants. Guidelines for the conduct of tests for distinctness, uniformity and stability for maize descriptor No. TG/2/6.

Welcker, C.; C. The; B. Andreau; C. De leon; S.N. Parentoni; J. Bernal, J. Felicite, C. Zonkeng; F. Salazar; L. Narro; A. Charcosset and W.J. Horst (2005). Heterosis and combining ability for maize adaptation to tropical acid soils. Crop. Sci., 45: 2405 - 2413. 


\title{
تقدير القدرة على التآلف وقوة الهجن والتمييز المورفولوجي لبعض سلالات الذرة الثامية والهجن الناتجة منها المورئا
}

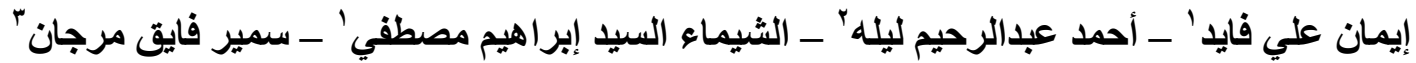

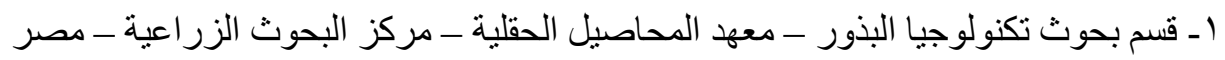 \\ r - قسم المحاصيل - كلية الزر اعة - جامعة المنصورة

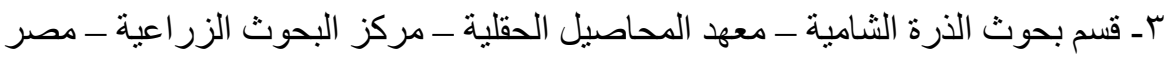

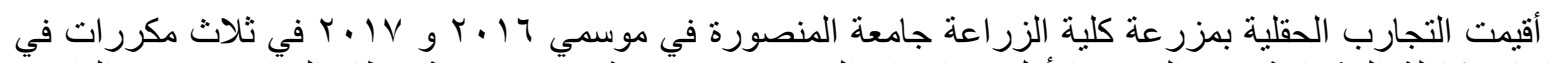

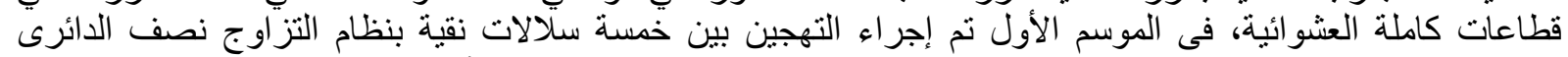

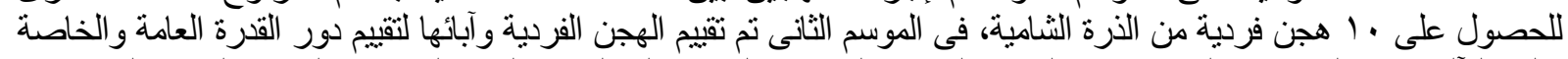

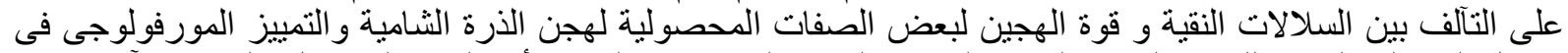

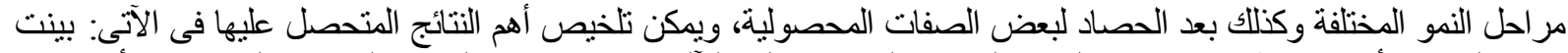

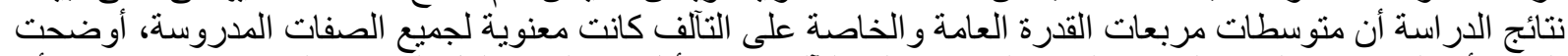

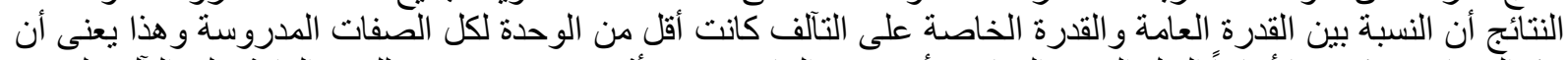

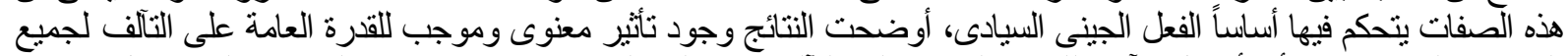

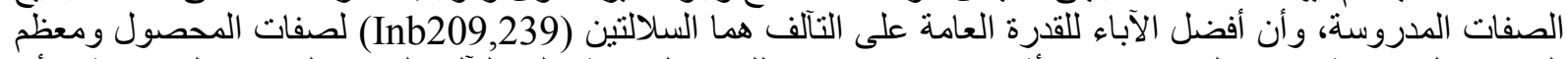

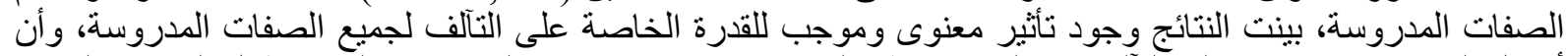

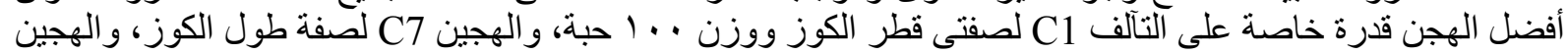

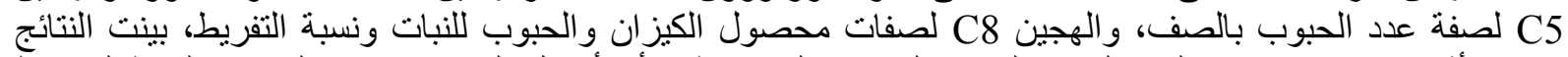

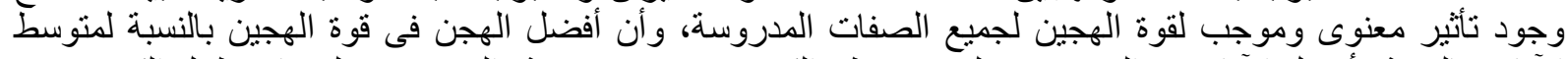

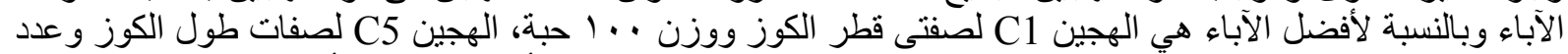

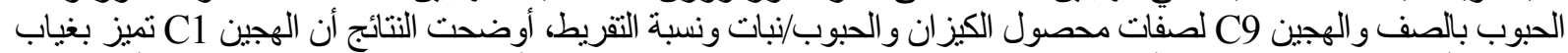

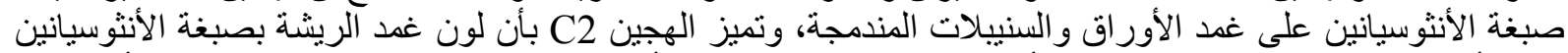

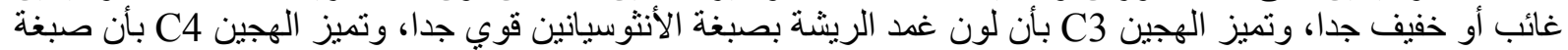

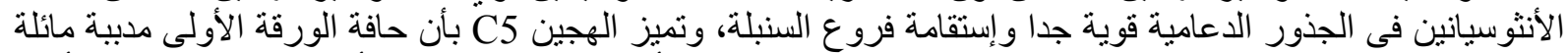

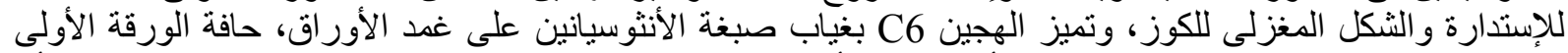

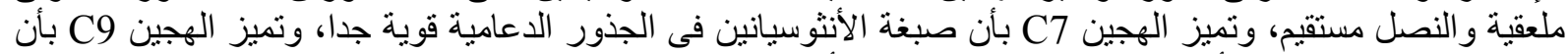

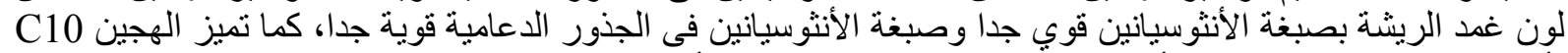

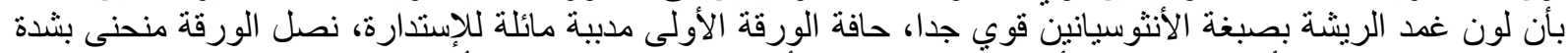

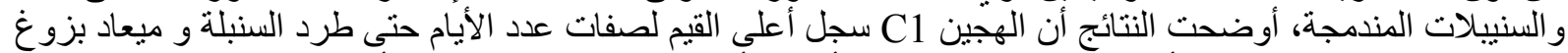

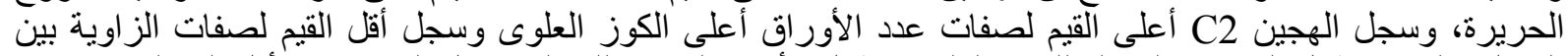

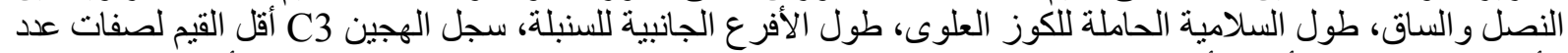

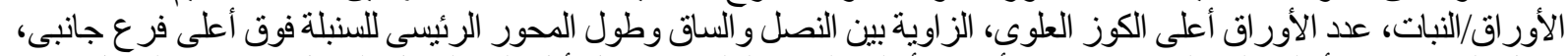

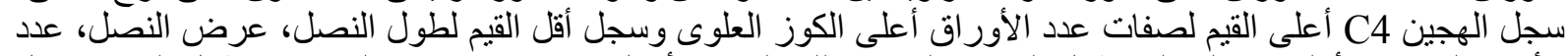

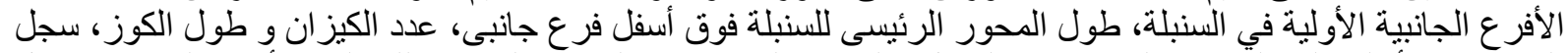

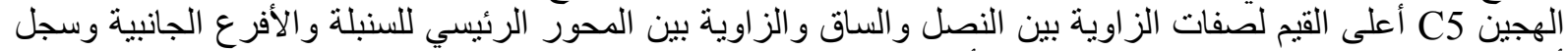

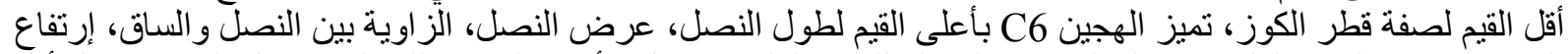

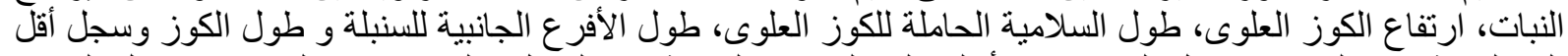

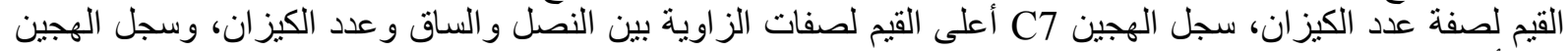

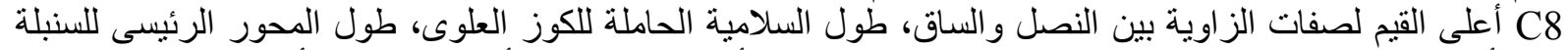

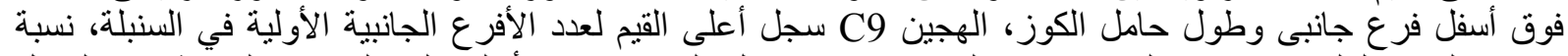

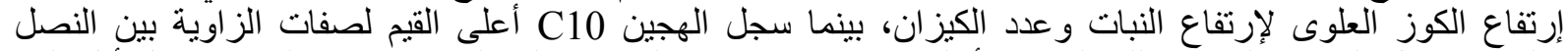

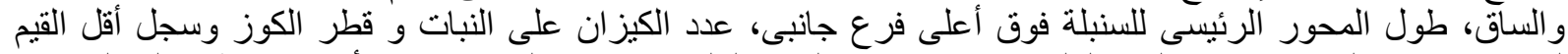

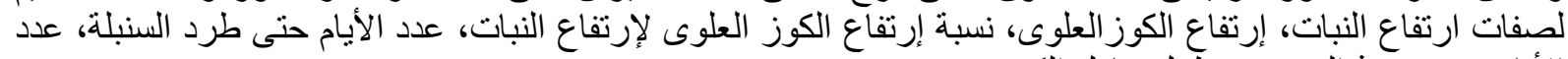
الأيام حتى بزوغ ألفرعات النبرة وطول حامل الكوز

أستاذ المحاصيل المتفرغ - كلية الزر اعة - جامعة أسيوط. أستاذ ورئيس قسم المحاصيل - كلية الزراعة الزعة - جامعة الزقازيق. 